\title{
CORVUS CAUDATUS.
}

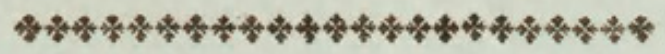

CHARACTER GENERICUS.

Rostrum convexum, cultratum.

Nares pennis setaceis recumbentibus obtectæ.

Lingua cartilaginea, bifida.

Pedes ambulatorii.

Lin. Syst. Nat. p. 155.

CHARACTER SPECIFICUS.

CORVUS nigro-virescens, capistro plumoso nigro, cauda longa cuneata.

Avis elegantis nondum forsitan descriptæ, in Africæ, ut vulgo creditur, generatæ dimidiatam magnitudinem depinximus. Si plumas erectas et quasi sericeas quibus rostri basis circumdatur respicimus, cognatio quadam videtur esse illi cum genere quod Paradisea dicitur: cætera autem corvo simillima est; cui generi fas sit ut annumeretur ve. luti species quædam anomala.

De modo vivendi nihil pro certo compertum est. 
2 जo: 
$\therefore$ is and +3 


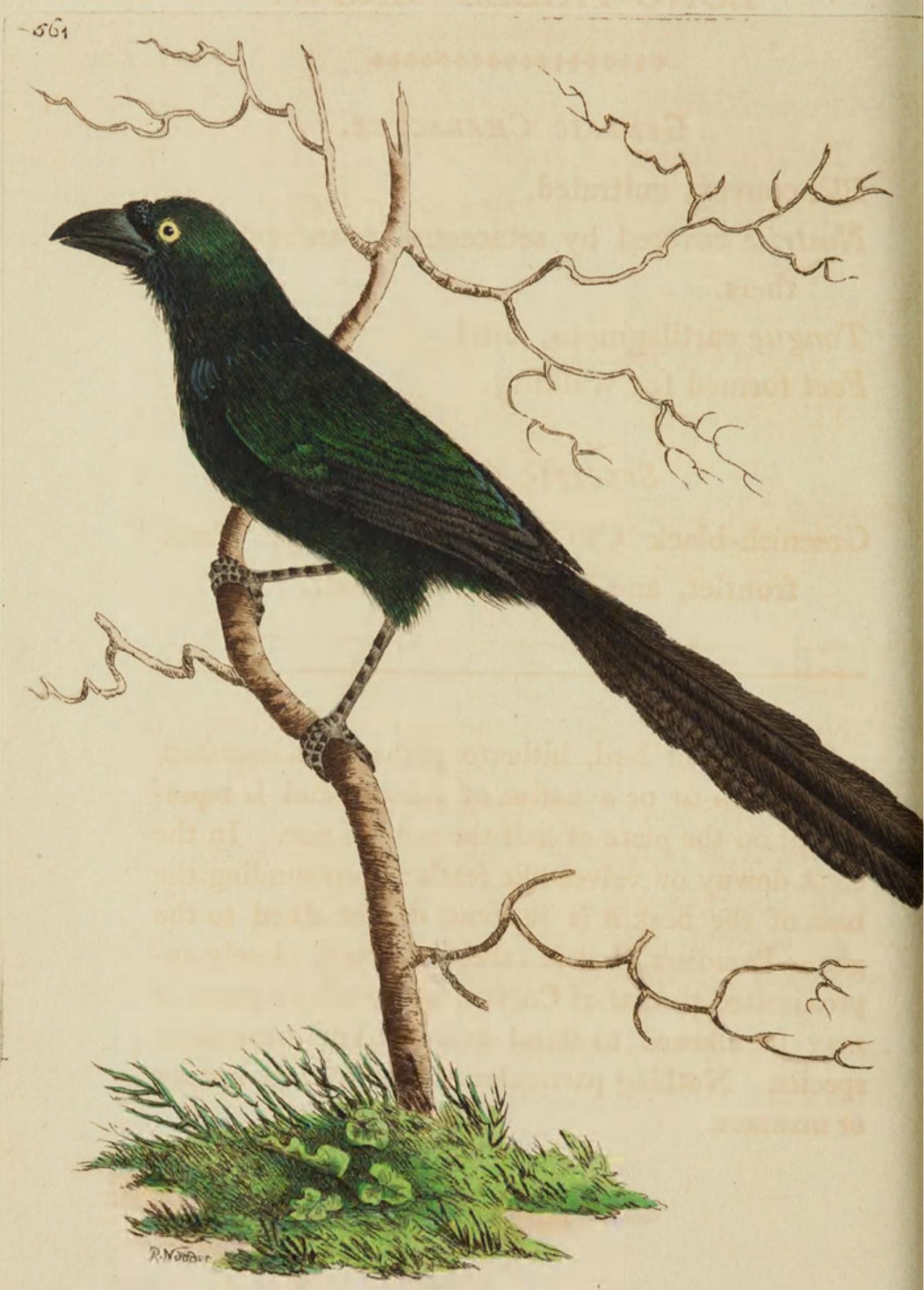




\section{THE \\ LONG-TAILED CROW.}

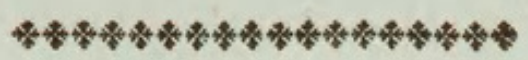

GENERIC ChaRACTER.

Bill convex, cultrated.

Nostrils covered by setaceous recumbent feathers.

Tongue cartilaginous, bifid.

Feet formed for walking.

\section{SPECIFIC CHARACTER.}

Greenish-black CROW, with downy, black frontlet, and long, cuneated tail.

This elegant bird, hitherto perhaps undescribed, is supposed to be a native of Africa, and is represented on the plate of half the natural size. In the erect downy or velvet-like feathers surrounding the base of the beak it is in some degree allied to the genus Paradisea, but in other respects is closely approximated to that of Corvus, under which genus it may be allowed to stand as a kind of anomalous species. Nothing particular is known of its history or manners. 


\section{$2 \mathrm{BHL}$ Biodiversity Heritage Library}

Shaw, George. 1803. "The Long-Tailed Crow, Corvus caudatus [PI. 561]." The Naturalist's Miscellany 14(CLXII), https://doi.org/10.5962/p.311006.

View This Item Online: https://www.biodiversitylibrary.org/item/278723

DOI: https://doi.org/10.5962/p.311006

Permalink: https://www.biodiversitylibrary.org/partpdf/311006

\section{Holding Institution}

Museums Victoria

\section{Sponsored by}

Atlas of Living Australia

\section{Copyright \& Reuse}

Copyright Status: Public domain. The BHL considers that this work is no longer under copyright protection.

This document was created from content at the Biodiversity Heritage Library, the world's largest open access digital library for biodiversity literature and archives. Visit BHL at https://www.biodiversitylibrary.org. 